\title{
Evolving the field: Interviews with Naomi Macalalad Bragin and Cara Hagan \\ Douglas Rosenberg
}

\section{Keywords:}

Screendance allyhood, Regards Hybrides, diversity, feminist, inclusive, aspirational spaces

\section{Initial statement}

Screendance seems to have had a few historical waves now. We know that dance or movement on screen had a simultaneous genesis with the very beginnings of optical media such as film and video. I would argue that the nexus between the performative body and its representation is linked as far back as representational media of all kinds including drawing and mark-making generally. It is clear that the dominant narrative of bodies in motion, on screens or mediated in any way, has been explicated through a western, Eurocentric lens. It is not a leap to say that even with the best of intentions, screendance suffers from the same systemic racism that we call out in other institutions generally. What is also clear is that the space of screendance is being populated by a new generation of makers, curators, scholars and theorists. This was evident to me in the event organized by Priscilla Guy and Emilie Morin in Montreal in the fall of 2019. Regards Hybrides: an International Forum ${ }^{1}$ was clearly representative of the new wave in screendance. I noted that it was a very generous space, thoughtfully articulated and critical without judgement. It was also largely feminist and queer and the curation created a platform for people of color, marginalized and/or indigenous groups to offer new narratives about screendance. The ensuing conversations and presentations juxtaposed much of what is missing in the screendance world against what we should be thinking about at this point in history. Given all the changes in the world since then, I have been thinking about how screendance can address questions of race, colonialism and oppression of all kinds with an eye toward evolving the field into a more egalitarian space. I am grateful to be able to share conversations here with Naomi Bragin and Cara Hagan, both of whose work I greatly admire.

\section{Questions to Naomi Macalalad Bragin}

DR: Naomi, I think / first encountered your work at a conference some years ago. Your voice made a huge impression on me. What you write about and how you write has introduced me to ideas and practices I would not otherwise have knowledge of. I was really thrilled to include your work in The Oxford Handbook of Screendance Studies ${ }^{2}$. I recall that the chapter you had written (which was fantastic) won an award and was published in a prestigious journal, so you wrote an entirely new and also deeply important chapter for the handbook. I was happy to meet you again at the forum and to hear your presentation as well. Your writing 
on street dance in Oakland California was prescient given the current state of the culture. You wrote about RIP videos and the "mourning culture" of East Oakland, which you described as including, "a hastily constructed street side altar [with] flowers and teddy bears propped at signposts" 3 , and images of recently passed loved ones circulating on $t$-shirts, etc. This seems all too familiar at present. You wrote about "turfing" as a dance practice that pays tribute to dead friends and family and described how many of the subsequent films circulate via YouTube and social media. Can you talk about how your writing from that moment helps us understand how screendance can illuminate the present, and also how we might expand the field to better incorporate such work into screendance generally?

NMB: Shot and Captured ${ }^{4}$ for me was really simply a love letter to Oakland and specifically to young people with whom I lived and worked intimately - the people and places who touched me and helped me to grow over twenty years, as an activist, educator and dancer. So the writing emerged and continues to emerge from a feeling of familiarity with a community, more than a desire to be incorporated into an academic field-though I am now institutionally bound up in the academic project and must contend with what all that means. It's a difficult, ambivalent, torn and imperfect story. There's things looking back I'd do differently. Yet the writing reflects what I felt moved to say in a particular moment. Oakland has a prolonged history of protesting policing and incarceration-to name a few the Black Panthers, Critical Resistance, Ella Baker Center, Let's Get Free, Books Not Bars, Underground Railroad, Youth Uprising. The article tries to site the ongoingness of this movement in black dance as an ethical bond between the living and the dead, and to to hopefully reframe attention to the spectacles of violence we, as social media users, consume when we interact with screens. I hoped in some small way to show dance as an everyday resource Black youth use to prepare-within a context of racialized violence which overlooks black life. Particularly in Oakland at that time, Turfing under the movement of gentrification gestured to a complex sense of embeddedness which Turfers practice in ways that reformulate a history of displacement.

DR: You participated in Regards Hybrides: an International Forum and talked about the intricacies of animating muscle groups and contraction in black dance forms such as popping and locking You mentioned "Black feminist poethics", (a term I found fascinating) in the context of Black feminist speculative practices. Your own book project Black Power of Hip Hop Dance: On Kinethic Politics 5 , builds a theory of "kinethics", drawing on Ferreira da Silva's work, I believe. Can you tell me more about this work?

NMB: Black Feminist Poethics ${ }^{6}$ is Denise Ferreira da Silva's call for a speculative praxis of uprooting racial capital's system of value and its ethical global order. So she's really calling for radical imagining, radical dreaming. What scholars may not know is she's also a dancer, so l'm super interested in how her work speaks to movement-which is how the idea of kinethics came about in my writing. Kinethics combines kinetic, kinship, ethics-aesthetics and kinesthetic, to describe emergent relations which dancers activate in practices of moving 
together, and to ask about the ethical consequences of these relations. In this book I study dances that originated in Black Power era California which have contributed to contemporary hip hop/streetdance culture-specifically black social dancing on Soul Train, popping, robot, and waacking/punking. I don't have the expertise for a comprehensive history - streetdance historians are the public scholars of that project and I learn from them-but I do feel this group of dances has some interesting stories to tell.

DR: Can you speculate a bit on how screendance might evolve in the future given the new generation of activist maker/curator/scholars that are working to change the field? How should it evolve?

NMB: The most important thing academics in any field can do to essentially prepare is deepen awareness of their institutional motivations and let go of investments in the institutionalization of knowledge projects. Diversity and inclusion is an institutional rhetoric engaged extensively by activist scholars like June Jordan, Jacqui Alexander, Sara Ahmed, Roderick Ferguson to Takiyah Amin and Nyama McCarthy-Brown's current work on diversifying dance pedagogies. Fred Moten and Stefano Harney's collaborative scholarship also offers a model for change. Especially in this moment, when the stakes of freedom are so violently amplified, I would like to see us less committed to titles and roles, and instead building our power to radically dream-into-being practices of caring for life which measure our proximity to collective liberation.

\section{Questions to Cara Hagan}

DR: Cara, I first met you at a workshop for screendance educators I was teaching with Katrina McPherson at The American Dance Festival in 2015. The workshop coincided with the $20^{\text {th }}$ anniversary of the ADF International Screendance Festival. It struck me at the time, that there was some sort of change coming to the field, though it was unclear what that would be. In a short essay at the time, I noted,

Over the last 20 years, Screendance has grown into an area of practice that is global, vibrant, and brimming with the possibilities of an art form that has gained a foothold in the cultures of both dance and media... Screendance, as an art form, is a part of a rich history and at the same time a part of an ever-evolving present, a part of the same technological evolution as social media, digital culture, and the global push toward the democratization of technological access.

That workshop felt important at the time and your activism on behalf of the screendance community (which was already in motion) has had an incredible impact. I know you have written a manifesto recently that will be included in your forthcoming book, tentatively titled, Action! Celebrating Screendance on the Film Festival Circuit. Can you share some of that and 
expand on your vision of what we need to do to make screendance a more diverse and politically aware space of representation?

$\mathrm{CH}:$ Curators must be dreamers:

We have to be able to imagine a world where ideas and expression can actually change the trajectory of history; that art can change the world. As we dream of what art can do, we must dream of creating the environment for it to do its best work; then we must create it.

As I have traveled around the world talking about issues of representation in screendance and on the screendance festival circuit, I cite three distinct barriers that I observe as hindrances to a more diverse and therefore multi-dimensional experience in screendance:

1. Financial Barriers

2. Cultural Barriers

3. Awareness Barriers

Though I imagine there isn't room [in this writing] to speak at length about each one, it is clear that since screendance is a labor of love for many - meaning largely self-funded - that a lot of people haven't been able to participate until more recently. The wider availability of good and user-friendly equipment is definitely changing the face of screendance, though in some respects, it's still slow-going. As we think about venues, organizations, and institutions where screendance appears often, we cannot dismiss the histories of those spaces that may dissuade people from marginalized identities from participating. As a community, we have to interrogate things like where we hold our events, who stands to profit off of them, and the ways they may be inaccessible to people in both real and perceived ways. Finally, it takes constant re-evaluation to be aware of trends we see across our discipline. Most especially those that may be problematic. As curators especially, it's our job to know what's happening across the field and to be able to observe and articulate the presence of patterns that give us insight into the zeitgeist of both the landscape of screendance, and our society at large.

DR: You curated a program of short films at Regards Hybrides. Can you talk about your curatorial practice specifically in relation to your choreographic practice, writing and activism? How does all this work support what I think is your larger commitment to social justice?

$\mathrm{CH}$ : As you may have gathered from my answer to the last question, I belive imagination is everything. For me, it isn't about the type of art that gets made. It's about cultivating the tools to do the work you dream of doing. It is about willfully reorganizing reality in a way that both recognizes and honors the inherent human capacity to make. My feeling is, that if we are creative enough to think of and to make real all the things that keep us from being just, 
empathetic, and a unified people, we need only think of the alternatives and believe in them enough to make them real. Race was created. The gender binary was created. Poverty was created. Lack of access to things like equal education, healthcare, and other public services was created. The concept of war, was created. Indeed, I believe that our inability to do something different socio-politically, is because of a lack of imagination. Thus, I write, I dance, I make film, I curate, because each of these modalities, each of these ways of being in the world offers me unique tools, while also offering me opportunities to utilize each tool in a way that supports or compliments the other tools. I don't mean to be simplistic. I understand that there are complex problems in the world that require us all to act, to be addressed. But then I think of all the amazing things that have happened throughout history, and how we have demonstrated that we are capable of solving socio-political issues including racism, White supremacy, misogyny, ableism, class stratification, and more.

DR: When I met you, I had an instantaneous idea that I wanted to offer you my position as Director of the ADF International Festival of Screendance. I realized that I would never be able to create the kind of contemporary energy around screendance that you could, given your previous work in the field and what I took to be your very progressive vision of screendance with the larger culture. Now some five years after you took over the role of director, you have indeed pushed the festival into spaces that I could only imagine. You have expanded the vision of the festival and you have become a significant voice internationally. Can you tell me a bit about your vision please? What is screendance at this moment and where will you push the field through your own work as a curator/activist/maker/scholar?

$\mathrm{CH}$ : In all honesty, my vision is simple: to support and champion screendance. When that's the goal, the rest flows from there. While I haven't yet been able to implement everything l'd like to do yet, I feel grateful to have been able to push to visibilize work that may not otherwise have been visibilized and to keep interrogating our definitions of screendance.

For the time being, screendance is multiplicitous. It's the festivals, it's commercial, it's video essays, it's TikTok, it's Instagram, it's zoom, it's the expendable experiments we make with our devices while we're stuck at home, it's the precious works made once in a lifetime. I don't wish to disrupt any of this. I only wish to encourage the community to keep digging into its own philosophies, accepted histories, and hopes, with the view of moving that information beyond itself. To keep its arms open for whoever else wants to play here. Screendance is bigger than me. I do what I can do.

DR: Final question: Being in the world at this moment, I am constantly reminded that we live in a society that is in need of repair. What has been so compelling to me in the overlapping phenomena of Black Lives Matter and the Covid-19 crisis is the preponderance of dance onscreen across virtually all media. More than just dance, it seems to be that the camera is the closest companion for many people. The ensuing performances for the camera from Zoom meetings to YouTube, TikTok and other means of transmission bring us face to face (so to speak) with the politics of our time, with protest and struggle and with a kind of framing 
and presentation quality that is not without artifice. It is not art per se but some kind of synthesis of the personal, the political, and the mediated moment. Ultimately, it seems we are witnessing a complete deconstruction of the visual culture of history and a new set of images about race and culture are rising in real time.

So, my question [to both of you] is how do we honor this moment in our own field (screendance) and what can our institutions and those of us who are committed to change do to ensure a progressive and egalitarian space for all?

NMB: This moment is both extraordinary and ordinary. For me that juxtaposition just shows up as a daily practice of feeling myself decentering -it's a practice in which I am just constantly falling and failing. It means becoming attuned to my in-the-moment motivations but not getting caught up in this omnipotent fear that I can't change or that I'm somehow innocent. It means recognizing and adapting my complicity with things academic. If I'm inevitably complicit with the institution, how can I shift its power, even infinitesimally, in the ways I structure the classroom, interact with students, imagine the boundaries of a field of study? And also cultivating the vulnerability to study myself and let go of myself all at once. Maybe that's where scholarship can be useful, because academia has not historically been about studying ourselves - especially our implication within these functioning power structures. Anyway, I'm leaning toward collectivities of gifted artists, activists and teachers who inspire and guide me. Academia is really just this centuries-old conversation (conversation in the sense of turning together). So l'd like to use that idea to attune more deeply to conversations and what they invite/activate creatively - wherever they take formation among whoever's gathering with me in the moment.

$\mathrm{CH}$ : We honor it by stepping back (to listen to those voices who have been silenced for too long) and diving in (to actively discover and test out new ways of being in the world) at the same time! We are all participants in this current moment. So while this means a suspension of doing things the way we have been, this moment is literally handing us an opportunity to do something different, with more awareness, and more hope. For me, it's helped to put things into perspective. What's really important? What can we let go of? What's worth keeping? And how do we expend our energy? With whom? Why? As of late, I've been scheduling zoom meetings with groups of screendance curators, practitioners, and educators to gather information about all of our experiences and identify how we want to organize and encounter screendance post-COVID. And while there are many possibilities that come to the fore, one thing that remains constant is the desire for us all to share space and resources. Screendance is defined by our collective endeavors. It serves us well not to forget that, and to use our powers of creativity and community for good.

\section{Author Biographies}

Naomi Macalalad Bragin is an assistant professor at University of Washington Bothell. She's currently developing her manuscript, Black Power of Hip-Hop Dance, and performance 
collaboration, Little Brown Language. She's received awards from Congress on Research in Dance, American Society for Theatre Research, and National Endowment for the Humanities. She is a former NYC Hip-Hop Theater Future Aesthetics Artist and Bay Area Isadora Duncan Best Choreography Nominee.

Cara Hagan is an artist whose practice exists at the intersections of movement, digital space, words, contemplative practice, and community. She is the director and curator for ADF's Movies by Movers, an annual, international screendance festival. She serves on faculty in the department of theatre and dance at Appalachian State University.

Douglas Rosenberg is an artist and a theorist and the author of Screendance: Inscribing the Ephemeral Image, as well as the editor of the Oxford Handbook of Screendance Studies, both published by Oxford University Press,. He is a founding editor of The International Journal of Screendance and his work for the screen has been exhibited internationally for over 25 years. He has been a long-time advocate of screendance as the founding curator of the International Screendance Festival at the American Dance Festival and as a speaker and organizer of symposia and international workshops. His most recent screendance is CIRCLING, a collaboration for the screen with Sally Gross, an original member of The Judson Dance Theater Group. Rosenberg is a professor in the Art Department at the University of WisconsinMadison.

\section{References}

Bragin, Naomi Macalalad. Black Power of Hip Hop Dance: on Kinesthetic Politics. Berkeley: University of California. 2015

Bragin, Naomi Macalalad. 'From Oakland Turfs to Harlem's Shake: Hood Dance on YouTube and Viral Antiblackness' in Rosenberg, Douglas ed., The Oxford Handbook of Screendance Studies. Oxford University Press. 2016. https://doi.org/10.1093/oxfordhb/9780199981601.013.33

Ferreira Da Silva, Denise. 'Toward a Black Feminist Poethics: The Quest(ion) of Blackness Toward the End of the World' in The Black Scholar: Journal of Black Studies and Research Volume 44, 2014 - Issue 2: States of Black Studies, published online 2015. https://doi.org/10.1080/00064246.2014.11413690

Regards Hybrides, November 21-24, 2019. 'Bodies and Motion Pictures from Scratch: Popular Culture and LowTech Screendance' Artistic director and curator Priscilla Guy (Canada) http://regardshybrides.com/en/

Rosenberg, Douglas ed., The Oxford Handbook of Screendance Studies. Oxford: Oxford University Press. 2016. https://doi.org/10.1093/oxfordhb/9780199981601.001.0001

\footnotetext{
Notes

${ }^{1}$ Regards Hybrides, 2019

${ }^{2}$ Rosenberg, ed., 2016

${ }^{3}$ Ibid., 541
} 
${ }^{4}$ Ibid., 537-556

${ }^{5}$ The manuscript has been selected for the Studies in Dance History series, which is published through the Dance Studies Association and the University of Michigan Press.

${ }^{6}$ Ferreira Da Silva, 81-97 